\title{
Activity of Sambiloto Extract (Andrographis paniculata Ness) in Reducing Total Blood Cholesterol Levels of Hypercholesterolemia Rats
}

\author{
Sudarmi \\ Universitas Veteran Bangun \\ Nusantara \\ Sukoharjo, Indonesia \\ sudarmi1959@yahoo.com
}

\author{
Wiwik Darmini \\ Universitas Veteran Bangun \\ Nusantara \\ Sukoharjo, Indonesia \\ wiwikdarmini58@gmail.com
}

\author{
Wartini \\ Universitas Veteran Bangun \\ Nusantara \\ Sukoharjo, Indonesia \\ wartiniskm.msc@gmail.com
}

\begin{abstract}
Cholesterol is one of the causes of coronary heart disease. The research objective is Assessing dosege of Sambiloto extract in reducing blood cholesterol levels rats (Rattus norvegicus) hypercholesterolemia. The research method is experimental, using Completely Randomized Design (CRD) 3 replications, 6 treatments are: 1) D0 = normal control; 2) D1 = positive control of cholesterol; 3) D2 = comparator simvastatin $2 \mathrm{mg} / 200 \mathrm{~g}$ body weight; 4) $\mathrm{D3}=$ dose of $100 \mathrm{mg}$ sambiloto/200 g body weight; 5) D4 = dose $200 \mathrm{mg}$ sambiloto / $200 \mathrm{~g}$ body weight; 6) D5 = dose of $400 \mathrm{mg}$ sambiloto/200 g body weight. Rats that have been tested are white male Wistar rats aged 2 months, weight $\pm 200 \mathrm{~g}$. Analysis using Anova, and further test using DMRT, $\alpha 5 \%$. The results of the experiment showed that sambiloto extract of $100 \mathrm{mg} / 200$ $\mathrm{g}$ body weight, $200 \mathrm{mg} / 200 \mathrm{~g}$ body weight; $400 \mathrm{mg} / 200 \mathrm{~g}$ body weight and a simvastatin comparator $2 \mathrm{mg} / 200 \mathrm{~g}$ body weight all of that can reduce the total cholesterol level of rats blood that be made hypercholesterolemia. Interestingly, the dose of $400 \mathrm{mg} / 200 \mathrm{~g}$ body weight has the same ability as simvastatin dose of $2 \mathrm{mg} / 200 \mathrm{~g}$ body weight in reducing total blood cholesterol levels of rats by $51 \%$, considering the risk of hypocholesterolemia.
\end{abstract}

Keywords-blood cholesterol level, hypercholesterolemia , Sambiloto extract

\section{INTRODUCTION}

Cholesterol is one cause of coronary heart disease (CHD). This heart disease is the most important caused of illness and death of advanced industrialized nations (Ariantari et al., 2010). In the United States, heart disease is the leading cause of death, which is about $37 \%$. About $88 \%$ of that figure is due to coronary heart disease [1].

Cholesterol is an essential ingredient in the body which is necessary to regulated the chemical processes in the body, but high cholesterol can lead to atherosclerosis which will eventually affect coronary heart disease [2].

Hypercholesterolemia is a condition the amount of blood cholesterol exceeds its normal limit.In the world of medicine is a compound sinamaldehid which is a derivative of a compound that has anti-bacterial and in vitro properties. In addition, other anti-oxidant compounds such as tannins and flavonoids are also expected to reduce cholesterol levels by smoothing LDL from the oxidation process to prevent atherosclerosis [3].
Sambiloto (Andrographis paniculata Ness) is one of the nine traditional medicines to be reviewed for clinical trials [4]. According to $\mathrm{WHO}$, about $65 \%$ of the population of developed countries and $80 \%$ of the population of developing countries have used herbal medicine as a traditional medicine. Chemical content of sambiloto is quite potential, namely: andrographolid, neoandrographolid, tannin, alkaloids, glycosides, flavonoids, all of those are the result of secondary metabolites [5]; [6], then sambiloto can be used as anti peritrik, anti hepatoksik, anti malaria, anti thrombogenic, HIV, anti-inflammatory, anti-fever, antibiotics, anti-diarrhea, anti-swelling and anti-diabetic and anti-hypercholesterolemia [7], [8], [9], [10]; [11].

Hypolipidemic/hypocholesterolemic drugs will cause dependence on the user and if used sustainably this drug will lead to disruption of other organ functions such as kidney function, liver, and lung [12]. Due to some side effects arising from hypolipidemia drugs it is necessary to seek other safer alternatives, such as the use of plants that have the potential for hypolipidemia.

Complete plants hipolipidemia is a plant that can decrease blood fat levels due to the active substances in cell phones. Exclusive plants of hypolipidemia have active ingredients such as flavonoids, tannins, andrographolid used as anti-oxidants [13]; [11]). Potential hypolipidemic plants that contain antioxidant compounds include sambiloto.

The efficacy of Sambiloto has been widely researched for healing various diseases. In 2000th Sambiloto has been clinically tested for HIV treatment that Andrographolide inhibits the dysregulation of HIV induced cell cycle [4]. According to [6], sambiloto extract can damage trophocyt and trophoblast cells, contributing to the cytoplasma condensation of tumor cells and destroying cancer cell nucleus [4] has observed the effects of the Sambiloto component on nitric oxide, endothelin, cyclic guanosine monophosphate, lipid peroxide and super-oxide dismutase, in a model of guinea pig that has atherosclerotic by administering a diet high in cholesterol. From the study said that sambiloto has antioxidant effects, maintain endothelial function, and maintain the balance of nitric oxide/endothelin that can help control blood cholesterol levels. Research on giving of sambiloto leaf extract for 21 and 28 days with a dose of $2,1 \mathrm{~g} / \mathrm{kg}$ body weight turned out to decrease total cholesterol, HDL, LDL. and triglyceride levels to near normal cholesterol/control [11]. 
Various testing of some plants to reducing blood cholesterol levels that have been done, among others: pineapple juice $100 \%, 80 \%$ and $60 \%$ pineapple can reduce total cholesterol levels in sequence of $152.59 ; 144,74$; $131,65 \mathrm{mg} / \mathrm{dl}$ and root extract of meniran dose $4 \mathrm{mg} / 200 \mathrm{~g}$ body weight can decrease total cholesterol level $11,59 \%$ [14]. Sambiloto extract should be tested to lower cholesterol levels.

Toxicology tests have been performed on experimental animals and show that andrographolide and other compounds in Sambiloto have very low toxicity. In mice given oral extract $(10 \mathrm{~g} / \mathrm{kg}$ body weight) once daily for 7 days, no mice died [4]). Heart, kidneys, liver and spleen are found in normal circumstances, it can be seen that sambiloto safe as herbal medicine [15]. In this research, Sambiloto extract has been tested for Rattus norvegicus wistar strains which have been conditioned by hypercholesterolemia with standard feeding (AD II) plus egg yolk and pork oil

Based on the description above, then formulated the problem as follows: Does Sambiloto extract activity can reduce blood cholesterol levels of rats conditioned by hypercholesterolaemia?

To examine the dose of Sambiloto extract to reduce blood cholesterol levels of rats conditioned on hypercholesterolaemia.

\section{METHODS}

The research was conducted from March 2018 to October 2018 at the Laboratory of the Faculty of Medicine UNS Surakarta. The research method was experimental, with Completely Randomized Design (RAL) 3 replications, 6 treatment doses: 1) D0 = normal control; 2) D1 = positive control of cholesterol; 3) D2 = comparative control of simvastatin $2 \mathrm{mg} / 200 \mathrm{~g}$ body weight; 4) D3 = dose of 100 $\mathrm{mg}$ sambiloto/200 g body weight; 5) D4 = dose $200 \mathrm{mg}$ sambiloto/ $200 \mathrm{~g}$ body weight; 6) $\mathrm{D} 5=$ dose $400 \mathrm{mg}$ sambiloto/200 g body weight. The animal test that used was male white rat Wistar strain of 2 months old, body weight \pm $200 \mathrm{gr}$ in healthy condition with characteristic of shiny and lively white fur [16]. The rats was adapted for one week with a temperature of $28^{0} \mathrm{C}$ before doing the research. After adapted rats conditioned hypercholesterolaemia, by means of egg yolk and pork oil. Then tested giving sambiloto extract for 14 days in a row. Total blood cholesterol was measured at day 7 (1 week after adaptation: day 14 (1 week after feeding high fat) 21 st day ( 2 weeks after feeding high fat) 28th day (1 week after ingestion test of sambiloto) and 35th day (2 weeks after administration of Sambiloto test material) Blood sampling was performed on blood vessel of experimental animals The results were analyzed using Analysis of Variance (Anova) and further test using DMRT, alpha 5\% [17]; [18].

\section{RESULT AND DISCUSSION}

Results of analysis of variance with $\mathrm{F}$ test of $5 \%$ level The total cholesterol $(\mathrm{mg} / \mathrm{dl})$ of mice in the treatment of hypercholesterol before and after high-fat feeding and giving of the sambiloto test were presented in Table 1 .
Table1. The F Test Results of $5 \%$ at all stages of observation of total cholesterol (mg/dl) of mice.

\begin{tabular}{cccc}
\hline No & $\begin{array}{c}\text { Stages Observation of } \\
\text { cholesterol levels in all } \\
\text { treatments }\end{array}$ & Price p & Sign \\
\hline 1 & One week acclimation (7th & 0,643 & $\mathrm{~ns}$ \\
2 & $\begin{array}{c}\text { day) } \\
\text { One week high-fat feeding } \\
\left(14^{\text {th }} \text { day) }\right.\end{array}$ & 0,002 & $* *$ \\
3 & $\begin{array}{c}\text { Two weeks of high fat diet } \\
(21 \text { st day) }\end{array}$ & 0.015 & $*$ \\
4 & $\begin{array}{c}\text { One week of giving of } \\
\text { sambiloto test (28th day) } \\
\text { Two weeks of giving } \\
5\end{array}$ & 0.001 & $* 2000$ \\
\hline Sambiloto test (35th day)
\end{tabular}

Based on the analyst of variance in table 1, that all treatments showing significant differences were tested further with 5\% alpha DMRT, the results can be seen in table 2 .

Table 2. Average blood cholesterol levels of mice on day 7, 14th and 21st days, 28th and 35 th days

\begin{tabular}{|c|c|c|c|c|c|}
\hline $\mathrm{T}$ & Total bl & $\mathrm{d}$ cholest & $\mathrm{ol}(\mathrm{mg} / \mathrm{d}$ & & \\
\hline & (1) & (2) & (3) & (4) & (5) \\
\hline D0 & $136.0 \mathrm{a}$ & $142.0 \mathrm{a}$ & $156.7 \mathrm{a}$ & $165.3 \mathrm{a}$ & $5.076 \mathrm{a}$ \\
\hline D1 & $158.3 \mathrm{a}$ & $191.3 \mathrm{~b}$ & $248.7 \mathrm{~b}$ & $268.0 \mathrm{c}$ & $\begin{array}{l}5.699 \\
\mathrm{c}\end{array}$ \\
\hline D2 & $154.3 \mathrm{a}$ & $174.7 \mathrm{~b}$ & $236.3 \mathrm{~b}$ & $179.3 \mathrm{~b}$ & $5.162 \mathrm{a}$ \\
\hline D3 & $145.0 \mathrm{a}$ & $183.3 \mathrm{~b}$ & $262.3 \mathrm{~b}$ & $218.0 \mathrm{~b}$ & $\begin{array}{l}5.401 \\
b\end{array}$ \\
\hline D4 & $136.3 \mathrm{a}$ & $199.7 \mathrm{c}$ & $249.7 \mathrm{~b}$ & $204.3 \mathrm{~b}$ & $\begin{array}{l}5.257 \\
b\end{array}$ \\
\hline D5 & $137.0 \mathrm{a}$ & $181.7 \mathrm{~b}$ & $297.0 \mathrm{~b}$ & $188.3 \mathrm{~b}$ & $\begin{array}{l}5.153 \\
\mathrm{a} \\
\end{array}$ \\
\hline
\end{tabular}

Remark: The values followed by the same letter at the same column showed non-significant difference at $5 \%$ DMRT

Description :

$\mathrm{T}$ :treatment

D0: normal control

D1: control +

D2: simvastatin (2 $\mathrm{mg} / 200 \mathrm{~g}$ body weight)

D3: $100 \mathrm{mg} / 200 \mathrm{~g}$ body weight)

D4: $200 \mathrm{mg} / 200 \mathrm{~g}$ body weight)

D5: $400 \mathrm{mg} / 200 \mathrm{~g}$ body weight)

(1) 1 Week Adaptation (7th day)

(2) High-fat feed (day 14)

(3) High-fat feed (day 21)

(4) Sambiloto test material (day 28)

(5) Sambiloto test material (35th day)

The results of checking blood cholesterol levels before feeding high cholesterol in the normal range and homogeneous variation $( \pm 152 \mathrm{mg} / \mathrm{dl})$, were almost stable for the normal control group treatment (D0) until the end of the research, so it deserves to be used as a blood cholesterol level in the beginning of the study. After high-fat diet for 1 week (day 14), blood cholesterol levels showed significant differences between normal control group (D0) and other high-fat-fed group (D1-D5) cholesterol levels but no hypercholesterolaemia occurred. So the feeding of high cholesterol is continued until day 21 (14 days), and it turns out hypercholesterolaemia.Furthermore, rats were given Sambiloto test material up to 14 days, because the average cholesterol level was still above the normal threshold $(>200$ $\mathrm{mg} / \mathrm{dl})$ when it was given for 7 days. Then, the statistical test of blood cholesterol level on the 28th day of observation (Sambiloto test material for 1 week) with $5 \%$ alpha DMRT test that D0 is significantly different from D2, 
D3, D4 and D5.Positive control group (D1: ie, high-fat feeding without testing material) also showed significant differences with normal control group (D0) or those given Sambiloto test material, and simvastatin (D2, as comparison). Animal testing of a positive control treatment (D1: high-fat feeding without test material until the end of the observation) also showed weight gain. While the treatment between D3, D4 and D5 was not significant. It shows that giving of Sambiloto test for 1 week, has been able to lower cholesterol level but cholesterol level still on the boundary of hiperkolesterolemia.The statistical test of blood cholesterol level on the 35th day of observation (giving of 2-week sample of Sambiloto test) with alpha 5\% DMRT test showed that positive control group D1 (experimental animal fed with high fat until the end of observation) showed very significant difference with treatment D0, D2, D5 and show significant differences with D3 and D4 treatment.The D3 treatment group (giving of $100 \mathrm{~g} / 200 \mathrm{~g}$ body weight) and D4 (giving $200 \mathrm{mg} / 200$ body weight of sambiloto sample) were not significantly different. D3 and D4 treatment group had similar ability in lowering cholesterol of experimental animals (42.02\%). Normal control group (D0); group simvastatin (D2: experimental animals given simvastatin $2 \mathrm{mg} / \mathrm{dl}$ test for comparison); and the treatment group D5 (giving of 400 $\mathrm{mg} / 200$ body weight of sambiloto test material) were not significantly different. It means Sambiloto extract dose of $400 \mathrm{mg} / 200$ body weight and simvastatin $2 \mathrm{mg} / 200 \mathrm{~g}$ body weight has the same ability in reducing total blood cholesterol of the experimental animal $(51.14 \%)$ but it is necessary to consider the risk of hypocholesterolemia. Widyawati (2007) said that the decrease of cholesterol level can be caused by various active substances in Sambiloto extract which have antioxidant effect, maintain endothelial function, and maintain the balance of nitric oxide/endothelin which can help control blood cholesterol level. In addition, the decrease in cholesterol levels allows the presence of fiber and vitamins from the standard AD II feed used.According to [19], the reduction of cholesterol and triglyceride levels by the fiber is done by binding free fatty acids and cholesterol in the form of bile acids when in the digestive tract, then excreted with feces. Fiber is also fermented by the microflora in the intestine, resulting in acetic acid, propionate and butyrate which can inhibit cholesterol synthesis.

\section{CONCLUSION}

Based on the research that has been done, it can be concluded that: 1) Sambiloto extract dose $100 \mathrm{mg} / 200 \mathrm{~g}$ body weight; $200 \mathrm{mg} / 200 \mathrm{~g}$ body weight; $400 \mathrm{mg} / 200 \mathrm{~g}$ body weight and simvastatin $2 \mathrm{mg} / 200 \mathrm{~g}$ body weight, all of these can reduce the total blood cholesterol of experimental animals and the dose of $400 \mathrm{mg} / 200 \mathrm{~g}$ body weight has the same ability with simvastatin dose $2 \mathrm{mg} / 200 \mathrm{~g}$ body weight in reducing total cholesterol levels in animal blood test is $51 \%$, but it is necessary to consider the risk of hypocholesterolemia.

\section{ACKNOWLEDGMENT}

Thanks to the Directorate of Research and Community Service, Directorate General for Research and Development
Reinforcement. Ministry of Research, Technology and Higher Education Subject to Contract Research Year 2018.

\section{REFERENCES}

[1] Ariantari, N., P., Yowani, S. C., Swastini, D. A, "Cholesterol Dicrease Activity Test Herbal Honey Products that are Circulating on the Market in High Fat Diety White Rats," Jurnal Kimia 4 (1) : 15-19, 2010 .

[2] Rahayu,T. Blood Cholesterol Levels of White Rat (Rattus norvegicus $L$ ) after Giving Kombucha Per-Oral Fluid. Jurnal Penelitian Sains dan Teknologi FKIP UMS 6 (2): 85 - 100. 2005.

[3] Azima, F. Antioxidant Activity and Platelet Anti-Aggregation of Extracts Grasisa vera (Cinnamomun burnanni Nees Ex Blume) and Its Potential in Prevention of Atherosclerosis in Rabbits. Disertasi. Institut Pertanian Bogor. 2004

[4] Widyawati, T. Pharmacological Aspects of Sambiloto (Andrographis paniculata Ness). Nusantara Medicine Magazine Volume 40 No.3 September 2007

[5] Yusron, M. Dan M. Januwati. Effect of Argoecological Conditions on the Production and Quality of Simplisia Sambiloto (Andrographis paniculata Ness.) Proceedings. National Conference on Indonesian Medicinal Plants. XXVI. Pokjarnas Indonesian Medicinal Plants. 211 231. 2004

[6] Winarto. Sambiloto Cultivation and Drug Use. Penebar Swadaya Jakarta. 2003

[7] Hanan, 1996. Some Important Notes About Sambiloto. Warta Tumbuhan Obat Indonesia. Kelompok Kerja Nasional Tumbuhan Obat Tradisional Vol. 3(1):9-16

[8] Dalimartha, S. 2003. Medicinal Plants. Penebar Swadaya. Jakarta.

[9] Sembiring, B.S., Feri, M dan M. Januawati. 2006. Effect of Material Ratio with Solvent and Extraction Length on the Quality of Andrographis paniculata Ness Extract. Proceedings. National Conference and exhibition of Indonesian Medicinal Plants XXVIII. Pokjanas Indonesian Medicinal Plants. 157-163

[10] Widowati, L. 2007. Provision of Sambiloto Extract Granules as Oral Antidiabetic Fitopharmaca. http://digilib.litbang.depkes.go.id accessed on July 13, 2007.

[11] Fatmawati, 2008. Effect of Time of Sambiloto Extract on Cholesterol, LDL, HDL and Blood Triglyceride Levels of Diadetes Rats. http://lib.uin malang ac.id

[12] Crish. 2008. Types of Fruits \& Afficacy http://morenicenews. blogspot. com/2008/11/manfaat-nanas-untuk-kesehatan.html. Diakses 12 Januari 2012

[13] Hicow. 2011. Reducing Cholesterol Levels Using Zocor.. http:// id. hicow.com/statin/low-density2791071.html Diakses 30 Januari 2012

[14] Fahri,C., Sutarno, S. Listyawati. Glucose and Cholesterol Levels Total blood of Hyperglycemic White Rats After Meniran Root Methanol Extract. Biofarma 3(1) : 1-6. Februari 2005 ISSN: 1693-2242. 2005.

[15] Astuti, Chozin dan Winarno, Hispatology of liver and kidney organ after administration of Andrographis paniculata Ness extract. Indonesian Medicinal Crops Research Institute, PUSLITBANG DEPKES RI. 2000

[16] Kusumawati, D. Friendly with Try Animals. Yogyakarta. Gadjahmada University Press. 2004.

[17] Anonim, Experiment Design. Faculty of Agriculture, Sebelas Maret University, Surakarta. 2007.

[18] Christensen, R. Analysis of variance, Design and Regression : Applied Statistical Methods. Chapman and Hall. London. 1996.

[19] Budiyono, W. dan Candra, A. Differences in Total Cholesterol Levels and Triglycerides Before and After Giving Green Grass Leaves (Premna oblongifolia Merr) in Dyslipidemia Mice. Journal of Nutrition College 2 